\title{
Use of Hydrophilic Insoluble Polymers in the Restoration of Metal-Contaminated Soils
}

\author{
Guiwei Qu ${ }^{1,2}$ and Amarilis de Varennes ${ }^{1}$ \\ ${ }^{1}$ Technical University of Lisbon, Tapada da Ajuda, 1349-017 Lisboa, Portugal \\ ${ }^{2}$ Soil and Environmental College, Shenyang Agricultural University, 110161 Shenyang, China \\ Correspondence should be addressed to Amarilis de Varennes, adevarennes@isa.utl.pt
}

Received 22 April 2009; Revised 24 June 2009; Accepted 19 September 2009

Recommended by Liliana Gianfreda

To develop cost-effective techniques that contribute to phytostabilization of severely metal-contaminated soils is a necessary task in environmental research. Hydrophilic insoluble polymers have been used for some time in diapers and other hygienic products and to increase the water-holding capacity of coarse-textured soils. These polymers contain groups, such as carboxyl groups, that are capable of forming bonds with metallic cations, thereby decreasing their bioavailability in soils. The use of polyacrylate polymers as soil amendments to restore metal-contaminated soils has been investigated in the Technical University of Lisbon since the late nineties. Plant growth and plant nutrients concentrations, extractable levels of metals in soil, and soil enzyme activities were used to monitor the improvement in soil quality following the application of these polymers. In contaminated soils, hydrophilic insoluble polymers can create microcosms that are rich in water and nutrients (counterions) but only contain small concentrations of toxic elements; the conditions of these microenvironments are favorable to roots and microorganisms. In this paper we described the most relevant information available about this topic.

Copyright ( 2009 G. Qu and A. de Varennes. This is an open access article distributed under the Creative Commons Attribution License, which permits unrestricted use, distribution, and reproduction in any medium, provided the original work is properly cited.

\section{Introduction}

Contamination of soils with toxic metal elements is of great concern to scientists and the general public. Longterm intake of contaminant metals by humans may lead to chronic effects, although maximum acceptable limits in food were already established for several toxic elements by the European Food Service Authority and the U.S. Food and Drug Administration.

Effects of metals on ecosystems and biological resources are also increasingly recognised [1-6]. Metals do not degrade as organic compounds do and have long residence times in soils. They can however exist in different forms, being water soluble (ionic and chelated with soluble compounds), adsorbed on soil surfaces, chelated by insoluble organic matter, precipitated, occluded by soil oxides and hydroxides, present in living organisms or residues, and as part of primary and secondary minerals [7]. Factors that influence the flow of metals from solid phases towards soil solution will govern their mobility and bioavailability [7].
Ideally, a contaminated soil should be restored to regain its original potential, but this can be a very expensive process, and thus depends not only on the expected benefit of the cleanup and future value of the soil, but also on political and public awareness of the problem. Conventional remedial approaches to severely metal-contaminated soils involve removal and replacement of soil with clean materials or capping the soil with an impermeable layer to reduce exposure to contaminants [8], although these are not considered the most economically or environmentally sound solutions available. According to Tordoff et al. [9], only through the establishment of a vegetation cover to stabilise metal-contaminated soils, a successful long-term rehabilitation will be achieved. However, as these sites are very unfavorable environments for plants, soil amendments are usually needed to reduce the bioavailability of metals and restore the ecological function of the soil $[10,11]$.

When soil acidity is the main constraint for the establishment of vegetation, it is common practice to apply liming materials $[12,13]$ or lime-stabilized biosolids $[10,14]$. 
A greater $\mathrm{pH}$ causes an increase in soil negative charges, resulting in enhanced cation adsorption, and in the formation of hydroxyl species of metal cations that are less soluble or have greater affinity for adsorption sites.

In most cases, a correction of soil $\mathrm{pH}$ is not sufficient, and organic amendments are used to improve soil physical, chemical, and biochemical properties $[5,6,8,10,12]$. Organic amendments can decrease metal bioavailability, by shifting from "plant-available" forms, extractable with water or solutions of neutral salts such as $\mathrm{CaCl}_{2}$, to less soluble forms. The extent and consequences of the changes depend upon the particular metal and soil type, and also upon the characteristics of the amendment used.

Biodegradable organic residues, such as manure and biosolids, can promote plant growth by adding essential nutrients for plants, increasing the organic matter content of the soil, raising the $\mathrm{pH}$, increasing the water-holding capacity, and decreasing metal bioavailability [15-19].

Synthetic polymers, such as polyacrylates or polyacrylamides, are another type of organic materials. Some of these polymers have large molecular weights and swell to form gels that contain many times their dry weight in water. They are marketed as "superabsorbent polymers", with different trade names, for incorporation into soils and substrates.

YunKai et al. [20] reviewed the effects of application of insoluble polymers to agricultural soils and crops. In this paper, we will describe the information available on the effect of hydrophilic insoluble polymers on plant growth and quality of metal-contaminated soils, with particular emphasis on polyacrylates, derivatives of acrylic acid with long chains containing carboxylic groups neutralized by $\mathrm{Na}^{+}$, $\mathrm{K}^{+}$, or $\mathrm{NH}_{4}{ }^{+}$. They are used as soil amendments but also in diapers, paper towels, and feminine products. It is estimated that over $130 \mathrm{Gg}$ of polyacrylates are used annually in such products [21].

Most of the information on the use of polyacrylate polymers to restore metal-contaminated soils derives from research carried out since the nineties in the Technical University of Lisbon. Hydrophilic insoluble polymers may enhance plant growth by three main processes: (i) increased supply of the nutritional cation present as counter ion, (ii) increased water-holding capacity of the soil and an enhanced supply to plants, (iii) decreased bioavailability of toxic metals due to chelation and ionic bonding.

In neutral or slightly acidic soils, the application of polyacrylate polymers does not change soil $\mathrm{pH}$, but in very acidic soils, polymers can increase $\mathrm{pH}$ by exchange of soil acidic cations with counter ions present in the polymer network [22]. This will also contribute to a smaller availability of toxic metals, although this effect is less important than their sorption by polymer.

\section{Supply of the Cations Present as Counterions}

Hydrophilic anionic polymers supply the cations present as counterions, which may contribute to plant nutrition if those elements are limiting plant growth. Enhanced plant content of the cation present in polyacrylates and polyacrylamides has been observed [23-26]. For example,

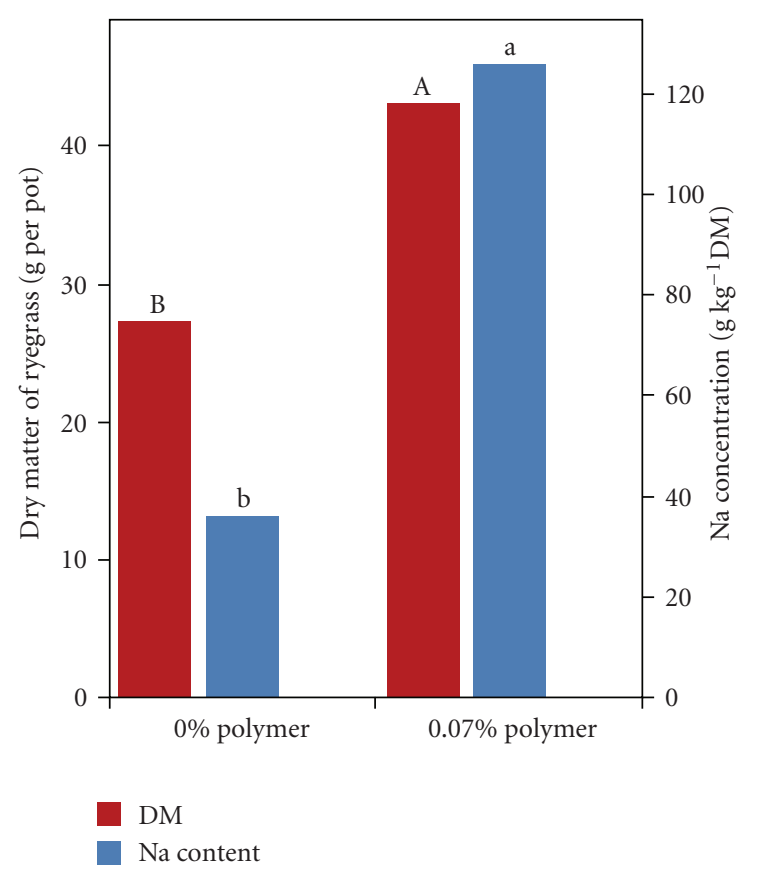

FIGURE 1: Yield and Na concentration of perennial ryegrass grown in a soil without or with $0.07 \%$ sodium polyacrylate polymer. A and $\mathrm{B}$ for dry matter, and a and $\mathrm{b}$ for $\mathrm{Na}$ concentration-statistically different as evaluated by the Newman-Keuls test at $P<.05$.

perennial ryegrass (Lolium perenne L.) grown in a sandy loam soil with $0.07 \%$ of a polyacrylate polymer with $\mathrm{Na}^{+}$ as counter ion (105 $\mathrm{mg} \mathrm{Na} \mathrm{g}^{-1}$ dry polymer) accumulated more $\mathrm{Na}$ than when it was grown in the same soil without polymer. As ryegrass is a natrophilic species [27], plant growth was also enhanced (Figure 1). However, unlike $\mathrm{K}^{+}$ or $\mathrm{NH}_{4}{ }^{+}$, the presence of $\mathrm{Na}^{+}$as a counter ion represents a disadvantage for most plant species. As discussed later, if polymers with $\mathrm{Na}^{+}$are to be used in phytostabilization of contaminated soils, Na-tolerant species have to be selected.

If the addition of the counter ion is taken into consideration within the experimental treatments, and proportionately less of the ion is added in the basal dressing, the positive yield difference is annulled (if water is not limited); usually the concentration of the element in shoots is the same in soil with or without polymer [28].

\section{Water-Holding Capacity of the Soil}

The use of hydrophilic polymers has been tested for some years to increase the water-holding capacity of coarsetextured soils [29-34]. The capacity of hydrophilic polymers to provide water to plants depends on the proportion of water held by the polymer that is easily available to plants, the pressure the soil exerts on the polymers and the presence of soluble salts.

In deionized water, some hydrophilic polymers can swell to retain 400 times or more of their dry weight as water $[31,35,36]$. When incorporated into soils, this gives rise 
to an increase in the water-holding capacity of the soil. For example, plant available water, as estimated by the difference between the amounts of water retained at -10 and $-1500 \mathrm{kPa}$, increased three folds when a polyacrylate polymer was incorporated into a sandy soil at $0.2 \%$ mixture with dry soil, compared with unamended control [37]. However, the expansion of the polymers is affected by the pressure exerted by the soil. For example, water retention was reduced from 258 to $65 \mathrm{~g}$ water $\mathrm{g}^{-1}$ dry polymer when a polyacrylate polymer was uniformly incorporated into $20 \mathrm{~cm}$-high soil columns, instead of being expanded in deionized water [37].

Swelling of hydrophilic polymers derives from electrostatic repulsion between the charges on the polymer chains and from the osmotic potential of the counter ions. Monovalent cations in solution reduce the osmotic imbalance and screen the polymer charges leading to a decrease in the waterholding capacity of the polymer, but on re-equilibration with de-ionized water, the polymers swell again [35]. Divalent or trivalent cations can lead to an irreversible collapse of polymers as discussed below.

\section{Bioavailability of Toxic Metals}

While stimulation of plant growth in uncontaminated sites derives mainly from the enhanced supply of water and nutrients brought about by hydrophilic polymers, in metalcontaminated soils, the bioavailability of toxic elements is critical for plant production.

In aqueous solutions, cations are rapidly trapped inside polyacrylates. Although hydration of the polymer decreases when exposed to monovalent cations, such as $\mathrm{K}^{+}$and $\mathrm{Na}^{+}$, on re-equilibration with de-ionized water, the polymer swells again. In contrast, exposure to metals such as $\mathrm{Cu}, \mathrm{Ni}, \mathrm{Cd}$, $\mathrm{Zn}, \mathrm{Mn}$, and $\mathrm{Cr}$ can lead to an irreversible collapse of the polymer (Figure 2). These metals form ionic crosslinks and coordination bonds with carboxylic groups in polyacrylates that prevent reexpansion of the polymer.

The first report on the chelation of a trace element by a polyacrylate polymer dates from 1954 and involves cupric ions [38]. A proportion of four carboxylic groups from polymer chains to each $\mathrm{Cu}$ ion was measured [36] suggesting that this is the number of ligands that participate in the formation of each complex.

The strength of the bonds between metals and polymer chains may be investigated by equilibrating the polymer containing a particular metal with different solutions capable of removing the element via cationic exchange or competition for chelation (Table 1).

An ionic solution $(2 \mathrm{M} \mathrm{KCl})$ providing a large excess of monovalent cations and commonly used to extract exchangeable cations in soil removed only $26 \%$ of the Cu but $68 \%$ of the Mn were held by a polyacrylate polymer (Table 1 ). Probably these ions were in exchangeable positions, held by electrostatic interactions.

To test the presence of covalent bonds between metals and polymer chains, acidic solutions with carboxylic groups were used. Ammonium acetate, with a single carboxylic group, did not compete with the polymer for the ions to any great extent. In contrast, ammonium EDTA, a strong chelator, removed all the $\mathrm{Cu}$ and $\mathrm{Mn}$ present in the polymer when the ratio of carboxylic groups was $17: 1$. When the ratio was equal to one, the solution of EDTA removed about half of the $\mathrm{Cu}$ and $\mathrm{Mn}$ present, suggesting that the strength of the polymer-metal bond is similar to that with EDTA. Probably, ions were linked by both ionic and covalent bonds within the polymer network; the proportion of these bonds depends on the type of metal.

The sorption of cations in free solution is a very fast process taking place within a few minutes and resulting in a visible collapse of the polymer. In contrast, this process is much slower when polymers are applied to soil, as the amount of the metal in solution is very small, and the movement of metals in soil is much slower than in free solution. In consequence, the time taken for the polymers to collapse is extended over a large period of time, but the process can still be followed, as the water-holding capacity of the soil slowly declines due to the formation of ionic bridges and chelates between metals and polymer particles. This can be measured by weighing the soil after it has been saturated with water. In a mine soil with $0.4 \%$ polyacrylate polymers, a decrease in maximum water-holding capacity from almost $700 \mathrm{~mL} \mathrm{~kg}^{-1}$ of soil to less than $400 \mathrm{~mL} \mathrm{~kg}^{-1}$ of soil was followed during approximately 60 days, while the maximum waterholding capacity of the unamended soil remained constant (Figure 3).

\section{Quality of Restored Soils}

The overall improvement in soil quality should be evaluated not only by determining soil chemical characteristics, measured by conventional analytical tests and extraction procedures, but also by determining habitat functions $[8$, 11]. In fact, chemical analysis is insufficient to evaluate potential ecological risks, since the combined effects of the different contaminants are not taken into consideration.

The effects of polyacrylate polymers on the quality of metal-contaminated soils have been accessed by measuring the activity of soil enzymes as well as determining levels of metals and plant growth.

The extractable levels of toxic metals in soils decreased following polymer application (Table 2). Depending on the extracting solution, metal and soil type decrease between $11 \%$ and $64 \%$ of the content of the unamended soil was observed. For example, in a loamy sandy vineyard soil heavily contaminated with $\mathrm{Cu}\left(230 \mathrm{mg}\right.$ EDTA-extractable $\mathrm{Cu} \mathrm{kg}^{-1}$ soil), the application of $0.1 \%$ polyacrylate polymer led to a decrease in the level of water-extractable $\mathrm{Cu}$ from 7.32 to $0.79 \mathrm{mg} \mathrm{kg}^{-1}$ of soil (11\% of unamended soil) [39]. In a multicontaminated sandy mine soil, the levels of waterextractable $\mathrm{Pb}, \mathrm{Cu}$, and $\mathrm{Zn}$ also decreased considerably, from $25,0.8$, and 0.2 to $16,0.4$, and $0.1 \mathrm{mg} \mathrm{kg}^{-1}$ of soil, respectively [40].

Soil enzymes catalyze biochemical reactions that are often related to nutrient cycling in soil (N, P, and C). These nutrients are generally essential to plants or soil organisms. The enzyme activity can be used as indicators of soil quality 
TABLE 1: Copper and manganese removed from a polyacrylate polymer* with different solutions.

\begin{tabular}{lccc}
\hline Solution & $\begin{array}{c}\text { Ratio of COOH groups } \\
\text { Solution : Polymer }\end{array}$ & Cu removed (\%) & Mn removed (\%) \\
\hline $2 \mathrm{M} \mathrm{KCl}$ & - & 26 & 68 \\
Ammonium acetate & $1: 1$ & 0.1 & 0.5 \\
Ammonium acetate & $10: 1$ & 4 & 18 \\
Ammonium EDTA & $1: 1$ & 45 & 52 \\
Ammonium EDTA & $17: 1$ & 100 & 100 \\
\hline
\end{tabular}

* Polymer was expanded in $5 \mathrm{mM} \mathrm{CuSO}_{4}$ or $\mathrm{MnSO}_{4}$ for 48 hours, excess water removed by filtration, and the polymer was left to equilibrate with the different solutions for 72 hours. These were filtered and the amount of $\mathrm{Cu}$ and $\mathrm{Mn}$ was analyzed in the filtrates by atomic absorption spectrometry.

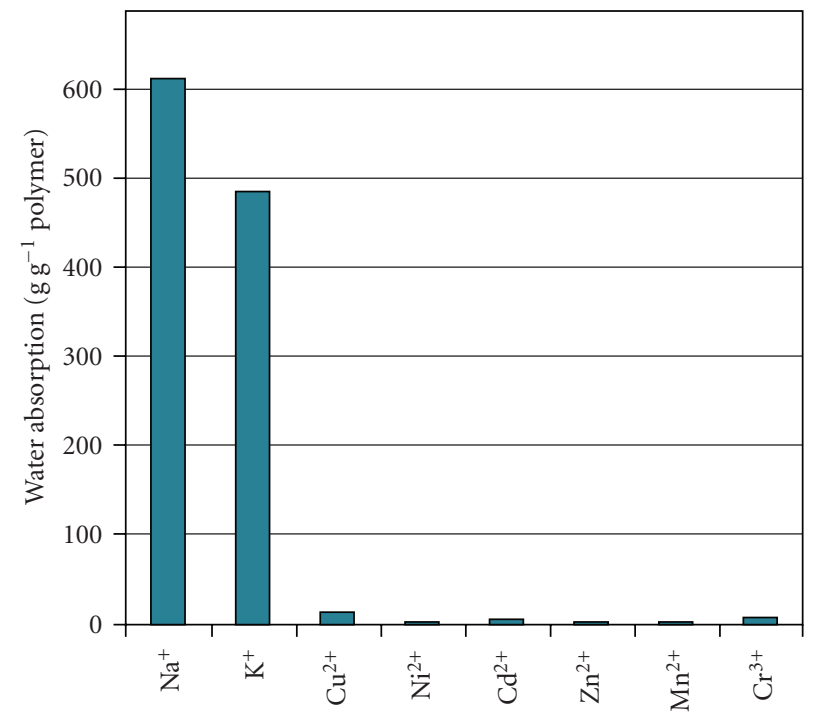

(a)
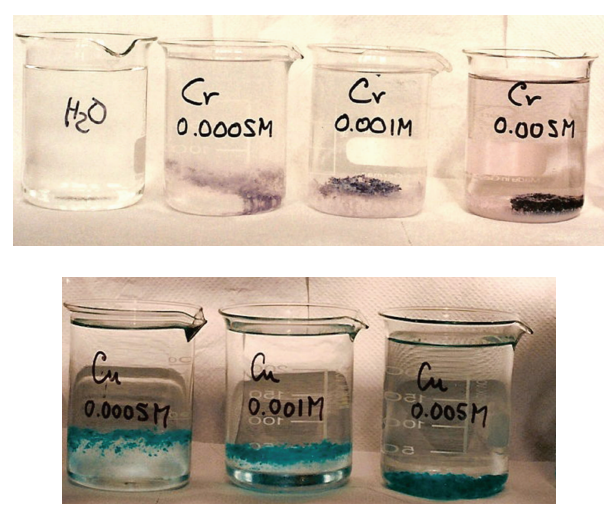

(b)

FIGURE 2: Dehydration of polyacrylates in the presence of different cations: (a) water absorption by a polyacrylate polymer after equilibration with $0.01 \mathrm{M}$ salt solution, filtration, and reequilibration with de-ionized water, (b) a polyacrylate polymer in the presence of increasing concentrations of $\mathrm{Cr}^{3+}$ (above) or $\mathrm{Cu}^{2+}$ (below).

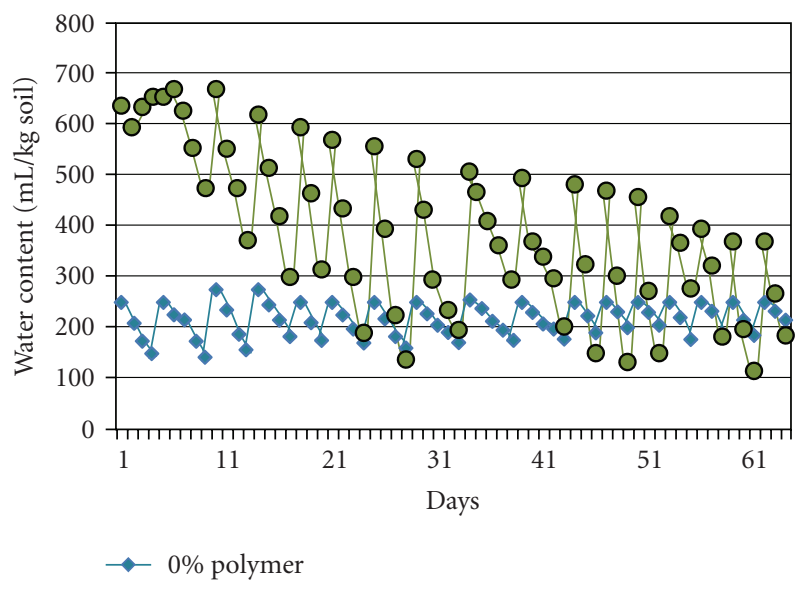

FIGURE 3: Changes in the water content of a mine soil without or with $0.4 \%$ polyacrylate polymers.

because of their relationship with soil biological processes and rapid response to changes $[4,41,42]$.
The activity of soil enzymes usually increases in polymeramended soils (Table 3). Dehydrogenase is an oxidoreductase present only in viable cells. Therefore, it can be used as an index of overall microbial activity $[4,43]$. Dehydrogenase was not stimulated by polymer application to a sandy soil with a total content of about $20 \mathrm{mg} \mathrm{Cd} \mathrm{kg}{ }^{-1}$ (of which about half was water-extractable), but it was enhanced in mine soils contaminated with $\mathrm{Pb}$, or with $\mathrm{Pb}, \mathrm{Cu}$, and $\mathrm{Zn}$, compared with the enzyme activities of the unamended control soil (Table 3). Although Cd is toxic towards soil microorganisms, severe adverse effects have generally only been detected at greater $\mathrm{Cd}$ concentrations than those of the monitored soils [44].

Other hydrolytic enzymes are present outside or inside living microbial cells [45]. Cellulases are enzymes that degrade cellulose, an important component of plant residues. $\beta$-glucosidase activity plays a critical role in the release of glucose that acts as energy source for soil microorganisms. Protease activity is involved in the release of amino acids (an important source of mineral N), and acid phosphatase is involved in the release of inorganic $\mathrm{P}$ 
TABLE 2: Extractable levels of metals in contaminated soils.

\begin{tabular}{lccc}
\hline Metals contaminating the soil & Extracting solution & Level of metals (\% of control) & Reference \\
\hline $\mathrm{Cu}$ & Water & 11 & {$[39]$} \\
$\mathrm{Pb}$ & $0.01 \mathrm{M} \mathrm{CaCl}_{2}$ & 63 & {$[22]$} \\
$\mathrm{Pb}, \mathrm{Cu}$, and $\mathrm{Zn}$ & Water & 64,50 , and 50 & {$[40]$} \\
$\mathrm{Cd}$ & $0.01 \mathrm{M} \mathrm{CaCl}_{2}$ & 57 & Unpublished results \\
\hline
\end{tabular}

TABLE 3: Enzyme activity of polymer-amended metal-contaminated soils.

\begin{tabular}{lcc}
\hline Metals contaminating the soil & Soil enzyme & $\begin{array}{c}\text { Increase in enzyme activity in amended soils } \\
\text { compared to unamended soils }\end{array}$ \\
\hline $\mathrm{Cu}$ & Acid phosphatase & 1.7 \\
$\mathrm{Cu}$ & $\beta$-glucosidase & 1.8 \\
$\mathrm{Cu}$ & Cellulase & Not stimulated \\
$\mathrm{Pb}$ & Dehydrogenase & 3.3 \\
$\mathrm{~Pb}$ & Protease & 11 \\
$\mathrm{~Pb}$ & Acid phosphatase & 1.9 \\
$\mathrm{~Pb}$ & $\beta$-glucosidase & 3.3 \\
$\mathrm{~Pb}$ & Cellulase & 11 \\
$\mathrm{~Pb}, \mathrm{Cu}$, and $\mathrm{Zn}$ & Dehydrogenase & 1.6 \\
$\mathrm{~Pb}, \mathrm{Cu}$, and $\mathrm{Zn}$ & Acid phosphatase & Not stimulated \\
$\mathrm{Pb}, \mathrm{Cu}$, and $\mathrm{Zn}$ & $\beta$-glucosidase & 1.5 \\
$\mathrm{Cd}$ & Dehydrogenase & Not stimulated \\
$\mathrm{Cd}$ & Protease & 1.5 \\
$\mathrm{Cd}$ & Acid phosphatase & 1.1 \\
$\mathrm{Cd}$ & $\beta$-glucosidase & 1.4 \\
$\mathrm{Cd}$ & Cellulase & 2.9 \\
\hline
\end{tabular}

in acid soils. Apart from cellulase activity of a vineyard soil contaminated with $\mathrm{Cu}$ and acid phosphatase activity of a mine soil contaminated with $\mathrm{Pb}, \mathrm{Cu}$, and $\mathrm{Zn}$, all other enzyme activities were stimulated by polymer application (Table 3).

Although they contain organic C, polyacrylate polymers are slowly degraded in soil [21] and thus the contribution to carbon nutrition of soil organisms is small.

Heavy metals interact with hydroxyl and sulfydryl groups and with nitrogen-containing ligands of enzymes, inhibiting their activity [2, 42, 47-49]. The decrease in the levels of metals in soil solution brought about by polymer application may thus be responsible for the stimulation of the activity of soil enzymes. However, high levels of toxic metals are not always associated with smaller enzyme activities in soil. For example, Belén-Hinojosa et al. [2] reported that the activities of arylsulfatase and alkaline phosphatase were similar in contaminated and in restored soils, while Kizilkaya et al. [3] found that urease activity was not correlated with the content of metals in arable soils.

According to Belén-Hinojosa et al. [1], soil type modulates the effect of metals on soil enzyme activity, explaining the contradictory results obtained by different authors. Organic matter content seems to be a major factor influencing the activity of soil enzymes such as phosphatases $[5,42]$. Several studies reported an increase in the activity of hydrolases following the addition of organic materials to soils $[5,6,41,50]$. The revegetation of metal-contaminated soils also leads to enhanced activity of several soil enzymes $[4-6,51]$. This may result from indirect effects on enzymatic activity due to the stimulation of microbial activity by the greater plant growth and consequent increases in the amount of root exudates and plant residues reaching the soil.

Enhanced growth of several plant species has been shown in metal-contaminated soils following application of polyacrylate polymers, including cultivated species such as perennial ryegrass, annual medic (Medicago polymorpha L.) and orchardgrass (Dactylis glomerata L.) grown in soils contaminated with $\mathrm{Cu}, \mathrm{Cd}, \mathrm{Pb}$ or multi-contaminated (Table 4). Depending on soil and plant species, the increase in plant growth varied between 4 and 3000 times than that of plants grown in unamended soil. The greatest increases were obtained in mine soils (Figure 4).

The modest decrease in the level of extractable metals in soils following polymer application (Table 3 ) may be insufficient to explain such an enhanced plant growth. Polyacrylate polymers seem to provide microcosms, rich in water and nutrients, and with small concentrations of toxic metals, where roots and microorganisms can proliferate. In fact, the polymer particles in amended soils are completely penetrated and enmeshed by roots. This means that the effects observed in bulk soil are very likely only a poor representation of 
TABLE 4: Relative growth of several cultivated species grown in soils contaminated with metals.

\begin{tabular}{|c|c|c|c|}
\hline & & Growth & \\
\hline Metals & Plant species & $(\times$ growth in unamended soil $)$ & Reference \\
\hline $\mathrm{Cu}$ & Perennial ryegrass & 11 & [39] \\
\hline $\mathrm{Cu}$ & Annual medic & 4 & {$[46]$} \\
\hline $\mathrm{Pb}$ & Orchardgrass & 3000 & {$[22]$} \\
\hline $\mathrm{Pb}, \mathrm{Cu}$, and $\mathrm{Zn}$ & Perennial ryegrass & 21 & {$[40]$} \\
\hline $\mathrm{Cd}$ & Orchardgrass & 6 & Unpublished results \\
\hline
\end{tabular}

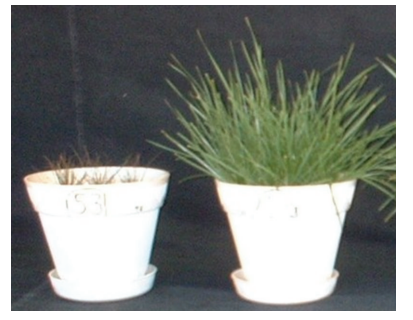

(a)

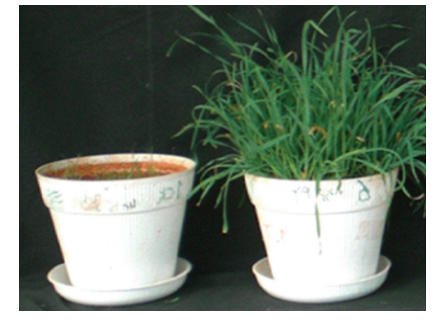

(b)

Figure 4: Growth of perennial ryegrass (a) and of orchardgrass (b) in mine soils without (left of picture) or with $0.2 \%$ (right of picture) of polyacrylate polymers.

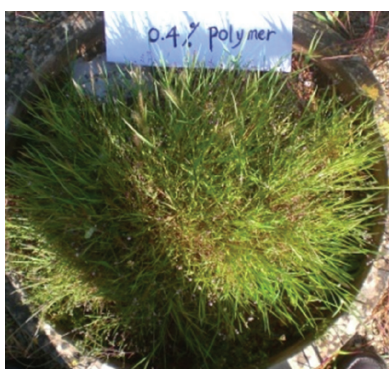

(a)

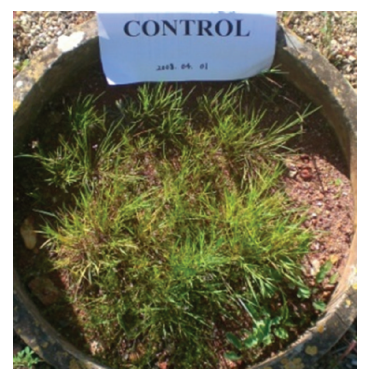

(b)
FIGURE 5: Growth of three species native to soils derived from a pyrite mine. Mine soil received $0.4 \%$ of polyacrylate polymers (a) or was left unamended (b).

the conditions in the rhizosphere, as polymer particles may act as screens around roots. This is supported by the fact that a polyacrylate polymer did not decrease water-extractable $\mathrm{Cu}$ in a $\mathrm{Cu}$-contaminated vineyard soil in the absence of plants. Plant exudates solubilized $\mathrm{Cu}$ and polymer particles competed with plants for Cu uptake [39].

Having established the mechanisms by which polyacrylate polymers may enhance plant growth in metalcontaminated soils, it was important to investigate the growth of plant species adapted to metal-contaminated sites as a result of polymer application. Seeds of Chaetopogon fasciculatus (Link) Hayek, Spergularia purpurea (Persoon) G. Don fil., and Andryala integrifolia L. were collected in a soil developed on pyrite mine wastes and were grown in cylinders $(60 \mathrm{~cm}$ diameter) with the mine soil either unamended or with $0.4 \%$ of polyacrylate polymers. Plant growth was stimulated in amended soil and the observed increase was enough to provide a full soil cover after five

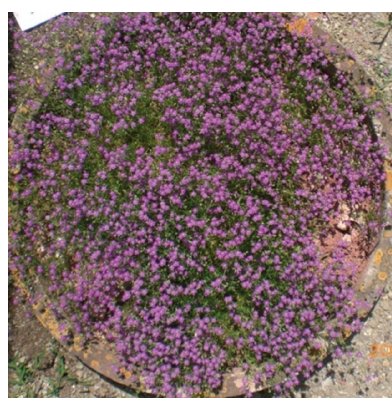

(a)

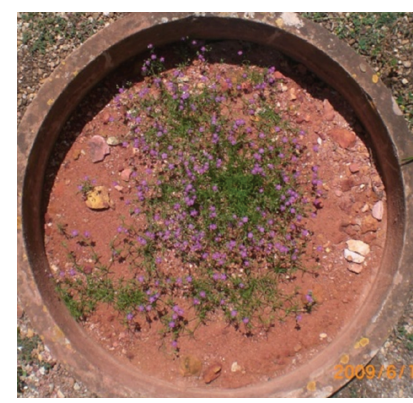

(b)
FIGURE 6: Growth of Spergularia purpurea in a soil derived from a pyrite mine. Mine soil received $0.3 \%$ shredded diapers per $\mathrm{kg}$ of soil (a) or was left unamended (b).

months as opposed to a soil that remained partially bare (Figure 5).

Commercial polyacrylate polymers cost about two Euros per kilogram, corresponding to eight Euros per ton of soil when these polymers are applied at a rate of $0.4 \%$. Although the total value is substantially smaller than that of conventional engineering approaches, which cost at least 40 Euros per ton of soil [52], cheaper alternatives should be sought when extensive areas of land are considered. Many diapers or similar products contain polyacrylate polymers [21] and these could become a potential local source of polymers at low cost. The use of residues containing polyacrylates to remediate mine soils is presently under investigation. Preliminary results suggest that shredded diapers can promote the growth of $S$. purpurea, which seems to tolerate the presence of $\mathrm{Na}^{+}$as counter ion (Figure 6).

Polyacrylate polymers are quite stable in soils, although they can be slowly degraded by white-rot fungi [53]. 
Although further studies are needed to investigate the duration of treatments, we have already known that they persist for at least one year (unpublished results).

\section{Conclusions and Outlook}

In conclusion, the application of hydrophilic insoluble polymers promotes plant growth due to increased waterholding capacity of the soil and enhanced supply of cations present as counter ions. The establishment of a plant cover in metal-contaminated soils is further promoted by the formation of microsites rich in water and nutrients and with a low level of toxic elements. This leads to a faster establishment of plants that provide full soil coverage that stabilizes the soil and enhances its quality.

\section{Acknowledgments}

This study was funded by projects PPCDT/AMB/57586/2004 and PPCDT/AMB/55312/2004 from the Portuguese Foundation for Science and Technology (FCT). Qu, Guiwei is grateful for the scholarship from FCT.

\section{References}

[1] M. Belén-Hinojosa, J. A. Carreira, R. García-Ruíz, and R. P. Dick, "Soil moisture pre-treatment effects on enzyme activities as indicators of heavy metal-contaminated and reclaimed soils," Soil Biology and Biochemistry, vol. 36, no. 10, pp. 1559 1568, 2004.

[2] M. Belén-Hinojosa, R. García-Ruíz, B. Viñegla, and J. A. Carreira, "Microbiological rates and enzyme activities as indicators of functionality in soils affected by the Aznalcóllar toxic spill," Soil Biology and Biochemistry, vol. 36, no. 10, pp. 1637-1644, 2004.

[3] R. Kizilkaya, T. Askn, B. Bayraklı, and M. Saglam, "Microbiological characteristics of soils contaminated with heavy metals," European Journal of Soil Biology, vol. 40, no. 2, pp. 95102, 2004.

[4] I. Izquierdo, F. Caravaca, M. M. Alguacil, G. Hernández, and A. Roldán, "Use of microbiological indicators for evaluating success in soil restoration after revegetation of a mining area under subtropical conditions," Applied Soil Ecology, vol. 30, no. 1, pp. 3-10, 2005.

[5] A. Pérez-de-Mora, J. J. Ortega-Calvo, F. Cabrera, and E. Madejón, "Changes in enzyme activities and microbial biomass after "in situ" remediation of a heavy metalcontaminated soil," Applied Soil Ecology, vol. 28, no. 2, pp. 125-137, 2005.

[6] A. Pérez-de-Mora, P. Burgos, E. Madejón, F. Cabrera, P. Jaeckel, and M. Schloter, "Microbial community structure and function in a soil contaminated by heavy metals: effects of plant growth and different amendments," Soil Biology and Biochemistry, vol. 38, no. 2, pp. 327-341, 2006.

[7] P. C. Srivastava and U. C. Gupta, Trace Elements in Crop Production, Science, Lebanon, Ohio, USA, 1996.

[8] S. Brown, M. Sprenger, A. Maxemchuk, and H. Compton, "Ecosystem function in alluvial tailings after biosolids and lime addition," Journal of Environmental Quality, vol. 34, no. 1, pp. 139-148, 2005.
[9] G. M. Tordoff, A. J. M. Baker, and A. J. Willis, "Current approaches to the revegetation and reclamation of metalliferous mine wastes," Chemosphere, vol. 41, no. 1-2, pp. 219-228, 2000.

[10] N. T. Basta, R. Gradwohl, K. L. Snethen, and J. L. Schroder, "Chemical immobilization of lead, zinc, and cadmium in smelter-contaminated soils using biosolids and rock phosphate," Journal of Environmental Quality, vol. 30, no. 4, pp. 1222-1230, 2001.

[11] S. Brown, R. L. Chaney, J. G. Hallfrisch, and Q. Xue, "Effect of biosolids processing on lead bioavailability in an urban soil," Journal of Environmental Quality, vol. 32, no. 1, pp. 100-108, 2003.

[12] M. H. Wong, "Ecological restoration of mine degraded soils, with emphasis on metal contaminated soils," Chemosphere, vol. 50, no. 6, pp. 775-780, 2003.

[13] P. Alvarenga, P. Palma, A. P. Gonçalves, et al., "Assessment of chemical, biochemical and ecotoxicological aspects in a mine soil amended with sludge of either urban or industrial origin," Chemosphere, vol. 72, no. 11, pp. 1774-1781, 2008.

[14] N. T. Basta and J. J. Sloan, "Bioavailablility of heavy metals in strongly acidic soils treated with exceptional quality biosolids," Journal of Environmental Quality, vol. 28, no. 2, pp. 633-638, 1999.

[15] R. P. Narwal and B. R. Singh, "Effect of organic materials on partitioning, extractability and plant uptake of metals in an alum shale soil," Water, Air, and Soil Pollution, vol. 103, no. 14, pp. 405-421, 1998.

[16] D. J. Walker, R. Clemente, A. Roig, and M. P. Bernal, "The effects of soil amendments on heavy metal bioavailability in two contaminated Mediterranean soils," Environmental Pollution, vol. 122, no. 2, pp. 303-312, 2003.

[17] D. J. Walker, R. Clemente, and M. P. Bernal, "Contrasting effects of manure and compost on soil $\mathrm{pH}$, heavy metal availability and growth of Chenopodium album L. in a soil contaminated by pyritic mine waste," Chemosphere, vol. 57, no. 3, pp. 215-224, 2004.

[18] P. Alvarenga, A. P. Gonçalves, R. M. Fernandes, et al., "Organic residues as immobilizing agents in aided phytostabilization: (I) effects on soil chemical characteristics," Chemosphere, vol. 74, no. 10, pp. 1292-1300, 2009.

[19] P. Alvarenga, P. Palma, A. P. Gonçalves, et al., "Organic residues as immobilizing agents in aided phytostabilization: (II) effects on soil biochemical and ecotoxicological characteristics," Chemosphere, vol. 74, no. 10, pp. 1301-1308, 2009.

[20] L. YunKai, Y. PeiLing, and L. HongLu, "Review on super absorbent polymers application in agriculture and its effects," Transactions of the Chinese Society of Agricultural Engineering, vol. 18, no. 2, pp. 182-187, 2002.

[21] J. E. Martin, "Environmental impact studies of the disposal of polyacrylate polymers used in consumer products," Science of the Total Environment, vol. 191, no. 3, pp. 225-234, 1996.

[22] Q. Guiwei, A. de Varennes, and C. Cunha-Queda, "Remediation of a mine soil with insoluble polyacrylate polymers enhances soil quality and plant growth," Soil Use and Management, vol. 24, no. 4, pp. 350-356, 2008.

[23] K. C. Taylor and R. G. Halfacre, "The effect of hydrophilic polymer on media retention and nutrient availability to Ligustrum lucidum," HortScience, vol. 21, no. 5, pp. 1159-1161, 1986.

[24] M. Silberbush, E. Adar, and Y. De Malach, "Use of an hydrophilic polymer to improve water storage and availability to crops grown in sand dunes I. Corn irrigated by trickling," 
Agricultural Water Management, vol. 23, no. 4, pp. 303-313, 1993.

[25] M. Silberbush, E. Adar, and Y. De Malach, "Use of an hydrophilic polymer to improve water storage and availability to crops grown in sand dunes II. Cabbage irrigated by sprinkling with different water salinities," Agricultural Water Management, vol. 23, no. 4, pp. 315-327, 1993.

[26] A. de Varennes, M. O. Torres, E. Conceição, and E. Vasconcelos, "Effect of polyacrylate polymers with different counter ions on the growth and mineral composition of perennial ryegrass," Journal of Plant Nutrition, vol. 22, no. 1, pp. 33-43, 1999.

[27] S. C. Jarvis and M. J. Hopper, "The uptake of sodium by perennial ryegrass and its relationship to potassium supply in flowing solution culture," Plant and Soil, vol. 60, no. 1, pp. 7383, 1981.

[28] A. de Varennes, M. Goss, and M. Mourato, "Remediation of a sandy soil contaminated with cadmium, nickel, and zinc using an insoluble polyacrylate polymer," Communications in Soil Science and Plant Analysis, vol. 37, no. 11-12, pp. 1639-1649, 2006.

[29] M. S. Johnson, "The effects of gel-forming polyacrylamides on moisture storage in sandy soils," Journal of the Science of Food and Agriculture, vol. 35, no. 11, pp. 1196-1200, 1984.

[30] S. El-Amir, A. M. Helalia, A. Wahdan, and M. E. Shawky, "Effect of two polymers on corn ( Zea mays L.) growth and water economy in sandy soils," Soil Technology, vol. 4, no. 2, pp. 177-181, 1991.

[31] D. K. C. Dhliwayo, "The effect of a superabsorbent on soil water retention of two soils and on the growth, development, and yield of winter wheat (Triticum aestivum L., cv. Pote)," Zimbabwe Journal of Agricultural Research, vol. 31, no. 1, pp. 53-64, 1993.

[32] R. E. A. Sabrah, M. F. Ghoneim, H. M. Abd El-Magid, and R. K. Rabie, "Characteristics and productivity of a sandy soil as influenced by soil conditioners in Saudi Arabia," Journal of Arid Environments, vol. 24, no. 3, pp. 297-303, 1993.

[33] R. K. Sharma and H. D. Verma, "Effect of irrigation scheduling and other agronomic manipulations on yield and water economy in sugarcane," Indian Journal of Agronomy, vol. 41, no. 1, pp. 122-126, 1996.

[34] O. A. El-Hady, S. M. Shaaban, and S. A. Wanas, "Hydrophilic polymers for improving the conditioning effect of manures and organic composts. I. Production and water and fertilizers use efficiency for tomato grown in sandy soil," Egyptian Journal of Soil Science, vol. 46, no. 1, pp. 79-90, 2006.

[35] Y.-T. Wang and L. L. Gregg, "Hydrophilic polymers-their response to soil amendments and effect on properties of a soilless potting mix," Journal of the American Society for Horticultural Science, vol. 115, no. 6, pp. 943-948, 1990.

[36] M. O. Torres and A. de Varennes, "Remediation of a sandy soil artificially contaminated with copper using a polyacrylate polymer," Soil Use and Management, vol. 14, no. 2, pp. 106110, 1998.

[37] A. de Varennes, A. Balsinhas, and M. J. Carqueja, "Effects of two polyacrylate polymers on the hydrophysical and chemical properties of a sandy soil, and on plant growth and water economy," Revista de Ciências Agrárias, vol. 20, no. 4, pp. 1327, 1997.

[38] F. T. Wall and S. J. Gill, "Interaction of cupric ions with polyacrylic acid," The Journal of Physical Chemistry, vol. 58, no. 12, pp. 1128-1130, 1954.
[39] A. de Varennes and M. Q. Torres, "Remediation of a long-term copper-contaminated soil using a polyacrylate polymer," Soil Use and Management, vol. 15, no. 4, pp. 230-232, 1999.

[40] A. de Varennes, C. Cunha-Queda, and A. R. Ramos, "Polyacrylate polymers as immobilizing agents to aid phytostabilization of two mine soils," Soil Use and Management, vol. 25, no. 2, pp. 133-140, 2009.

[41] F. Caravaca, A. Pera, G. Masciandaro, B. Ceccanti, and A. Roldán, "A microcosm approach to assessing the effects of earthworm inoculation and oat cover cropping on $\mathrm{CO}_{2}$ fluxes and biological properties in an amended semiarid soil," Chemosphere, vol. 59, no. 11, pp. 1625-1631, 2005.

[42] F. Gil-Sotres, C. Trasar-Cepeda, M. C. Leirós, and S. Seoane, "Different approaches to evaluating soil quality using biochemical properties," Soil Biology and Biochemistry, vol. 37, no. 5, pp. 877-887, 2005.

[43] P. Nannipieri, E. Kandeler, and P. Ruggiero, "Enzyme activities and microbiological and biochemical processes in soil," in Enzymes in the Environment: Activity, Ecology and Applications, R. G. Burns and R. P. Dick, Eds., pp. 1-33, Marcel Dekker, New York, NY, USA, 2002.

[44] J. L. Moreno, T. Hernandez, and C. Garcia, "Effects of a cadmium-contaminated sewage sludge compost on dynamics of organic matter and microbial activity in an arid soil," Biology and Fertility of Soils, vol. 28, no. 3, pp. 230-237, 1999.

[45] H. Cao, H. Sun, and H. Yang, "A review: soil enzyme activity and its indication for soil quality," Chinese Journal of Applied Environmental Biology, vol. 9, no. 1, pp. 105-109, 2003.

[46] A. de Varennes and C. Queda, "Application of an insoluble plyacrylate polymer to copper-contaminated soil enhances plant growth and soil quality," Soil Use and Management, vol. 21, pp. 410-414, 2005.

[47] N. G. Juma and M. A. Tabatabai, "Distribution of phosphomonoesterases in soils," Soil Science, vol. 126, no. 2, pp. 101108, 1978.

[48] E. Kandeler and H. Gerber, "Short-term assay of soil urease activity using colorimetric determination of ammonium," Biology and Fertility of Soils, vol. 6, no. 1, pp. 68-72, 1988.

[49] Q. Huang and H. Shindo, "Effects of copper on the activity and kinetics of free and immobilized acid phosphatase," Soil Biology and Biochemistry, vol. 32, no. 13, pp. 1885-1892, 2000.

[50] M. Tejada, M. T. Hernandez, and C. Garcia, "Application of two organic amendments on soil restoration: effects on the soil biological properties," Journal of Environmental Quality, vol. 35, no. 4, pp. 1010-1017, 2006.

[51] C. Zhang, L. Huang, T. Luan, J. Jin, and C. Lan, "Structure and function of microbial communities during the early stages of revegetation of barren soils in the vicinity of a $\mathrm{Pb} / \mathrm{Zn}$ smelter," Geoderma, vol. 136, no. 3-4, pp. 555-565, 2006.

[52] S. D. Cunningham and D. W. Ow, "Promises and prospects of phytoremediation," Plant Physiology, vol. 110, no. 3, pp. 715719, 1996.

[53] M. D. Cameron and S. D. Aust, "Degradation of chemicals by reactive radicals produced by cellobiose dehydrogenase from Phanerochaete chrysosporium," Archives of Biochemistry and Biophysics, vol. 367, no. 1, pp. 115-121, 1999. 

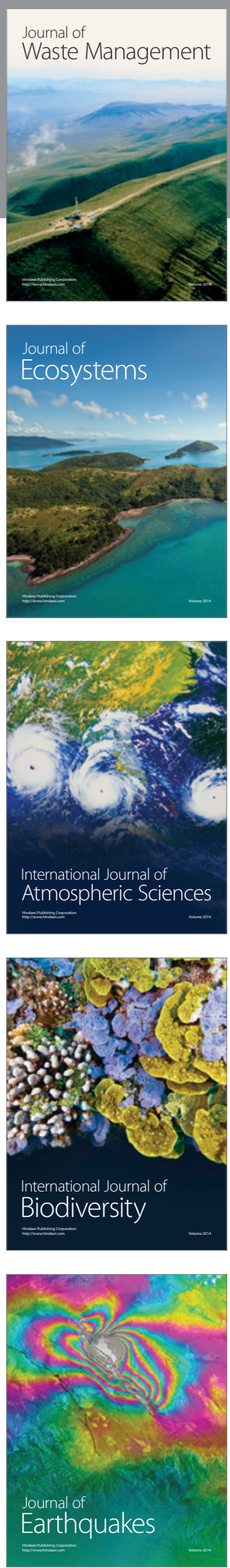
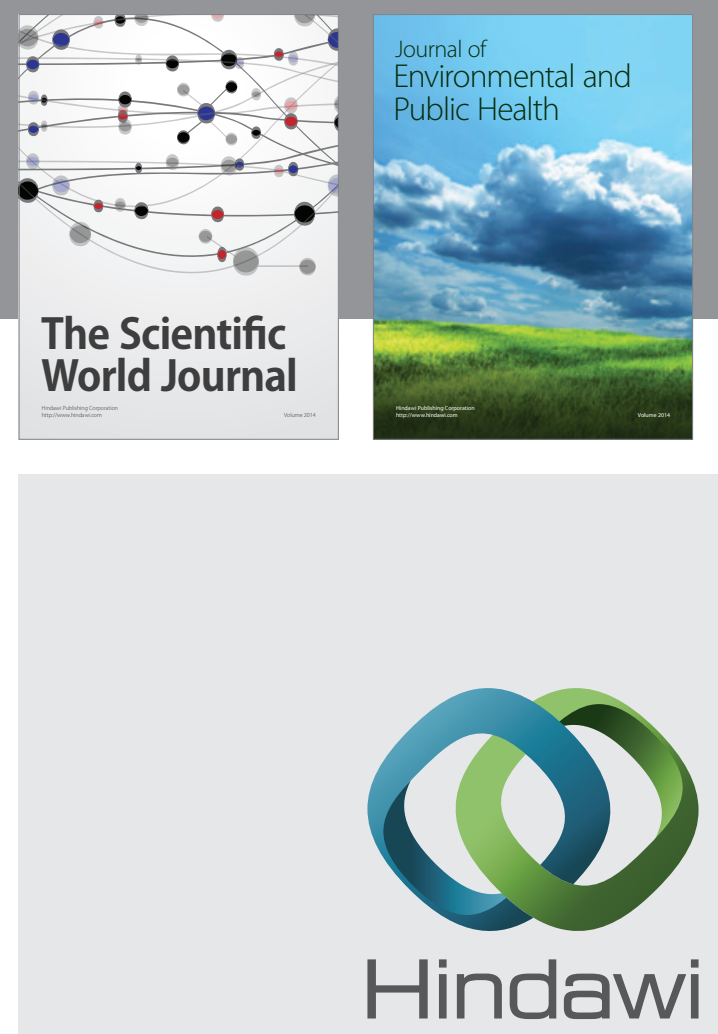

Submit your manuscripts at

http://www.hindawi.com
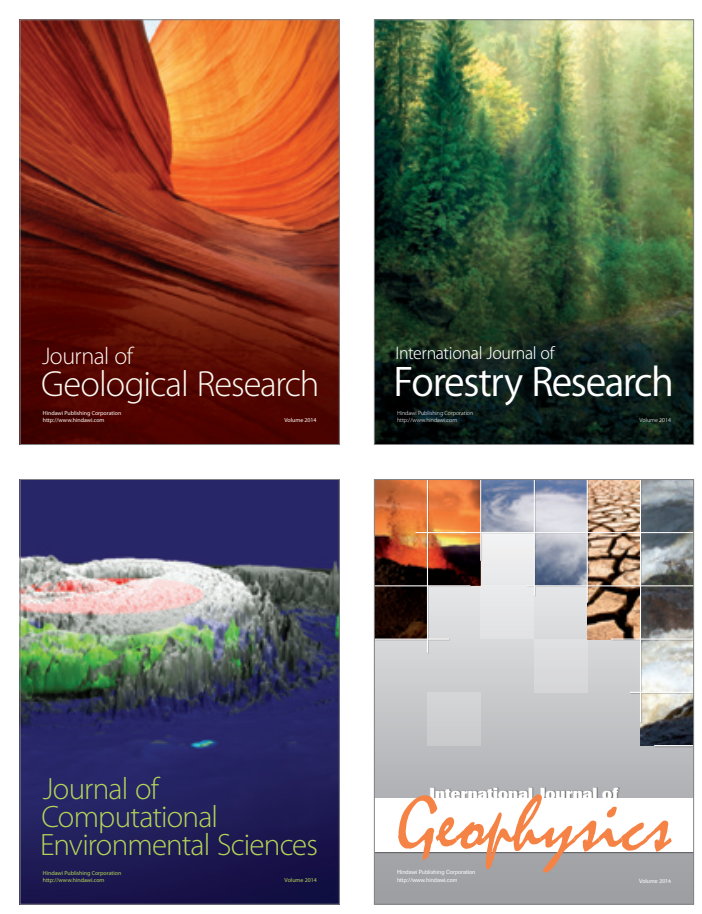
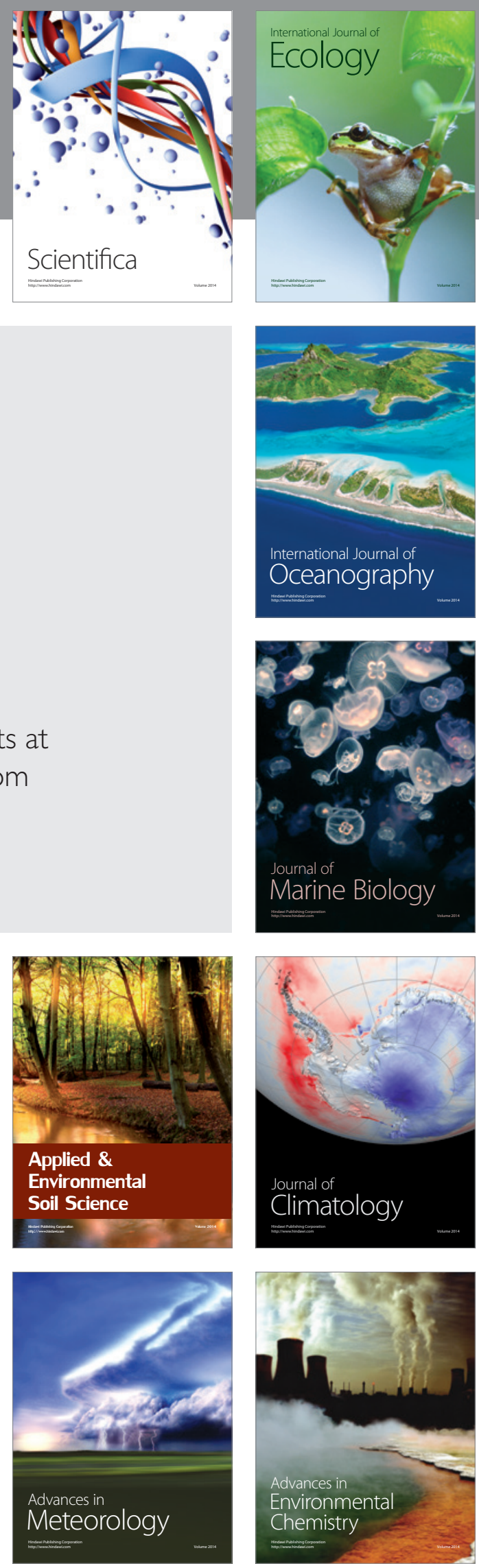